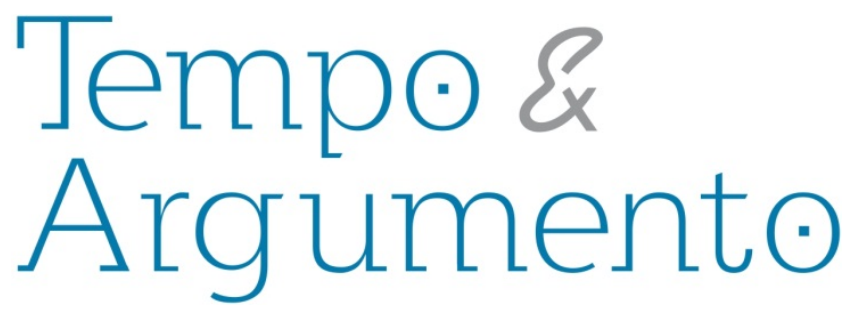

\title{
Maria Bueno e suas representações: reflexões teóricas sobre as crenças religiosas no Paraná - século XXI
}

\begin{abstract}
Resumo
O presente artigo objetiva tecer alguns apontamentos teóricos sobre as crenças religiosas no Paraná, a partir do caso de Maria Bueno, uma santa de cemitério de Curitiba, capital do referido estado, cuja morte ocorreu de forma violenta em finais no século XIX, rendendo-lhe distintas formas de representação e atraindo devotos na atualidade.
\end{abstract}

Palavras-chave: BUENO, Maria; Cemitérios -

Curitiba (PR); Fé.

\author{
Vanda Fortuna Serafim \\ Doutora em História pela Universidade Federal \\ de Santa Catarina - UFSC. Professora do \\ Programa de Pós-graduação em História da \\ Universidade Estadual de Maringá. - UEM. \\ Brasil \\ vandaserafim@gmail.com
}

\section{Tonia Kio Fuzihara Piccoli}

Mestranda em História na Universidade estadual de Maringá - UEM.

Brasil

tkfpiccoli@gmail.com

\section{Para citar este artigo:}

SERAFIM, Vanda Fortuna; PICCOLI, Tonia Kio Fuzihara. Maria Bueno e suas representações: reflexões teóricas sobre as crenças religiosas no Paraná - século XXI. Revista Tempo e Argumento, Florianópolis, v. 8, n. 18, p. 411 - 444. maio/ago. 2016. 
Maria Bueno and her representations: theoretical reflection on religious beliefs in Paraná - 21st

\title{
century
}

\begin{abstract}
This article aims to make some few theoretical notes on the religious beliefs in the State of Paraná, from the case of Maria Bueno, a Cemetery Saint in Curitiba, the capital of this state. She was murdered with violently death which occurred in late Nineteenth Century, giving her different forms of "representation" and attracting devotees nowadays.
\end{abstract}

Keywords: BUENO, Maria; Faith; Cemitérios Curitiba (PR).

No início do século XXI, Pierre Sanchis (2001) indicava que o campo religioso tornava-se cada vez mais homogêneo, em especial, nas suas institucionalizações históricas. E, o autor apontava ainda, que as manifestações que o invadem tendem a se reencontrar, organizadas em torno das injunções concretas de uma vida quotidiana objetiva ou subjetivamente vivida na precariedade e que esse fenômeno apontaria para uma multiplicidade das apreensões de sentido.

Dessa forma, haveria um novo tipo de religiosidade, que escaparia, mais ainda que no passado, ao controle efetivo dos aparelhos religiosos. Uma intensificação da religiosidade sem que por isso as religiões deixem de ver definhar o seu papel social. Esse formato que se estabeleceria em finais do século $X X$, não poderia ser definido pelos vieses da 'religião' ou das 'religiões', mas da religiosidade. A partir desta constatação, Sanchis indagava se a religiosidade precisa necessariamente remeter a uma instituição ou se poderia ela se organizar de forma autônoma. 
Exposto isso, a inquietação que delineia e instiga as reflexões aqui apresentadas consiste em compreender a devoção a Maria da Conceição Bueno e suas representações ${ }^{1}$, enquanto santa de cemitério na atualidade. Maria da Conceição Bueno (Rio da Prata, 8 de dezembro de 1854 - Curitiba, 29 de janeiro de 1893) é uma santa de cemitério em Curitiba, no estado do Paraná, chamada de forma carinhosa por seus fiéis de "santinha de Curitiba" 2 .

Existe grande variedade de documentos para analisar Maria Bueno, desde jornais, peças de teatro, relatos de memorialistas, fontes orais, programas de televisão e a própria cultura material. Esta variedade, todavia, não poderia ser exaurida e, sequer, apresentada em sua totalidade, em um artigo científico. Em virtude disto, a opção por pensar as representações de devotos que visitam o seu túmulo no dia de Finados, recorrendo aos demais elementos na medida em que forem necessários para a explicação histórica.

Não se opta por traçar uma cronologia sobre Maria Bueno e elencar os eventos que permitiriam sua configuração enquanto santa de cemitério, embora fosse, sem dúvida, tentador, uma vez que no âmbito do estudo das devoções religiosas esses elementos pouco importam e os significados surgem a partir dos indivíduos que os atribuem a partir de distintas visões de mundo.

Para a história, cultuar santos em seus jazigos não é novidade; para ser mais exato, foi exatamente assim que os primeiros cultos aos santos começaram. Nos primórdios do cristianismo, como atesta a historiadora Solange Ramos de Andrade (2010), os devotos dos primeiros santos se dirigiam para onde estes estavam enterrados e lá faziam orações, pedidos de intersessão e depositavam oferendas. Com o tempo, para abrigar essas relíquias depositadas por seus fiéis, foram sendo construídas capelas ao redor desses

\footnotetext{
${ }^{1}$ O conceito aqui é utilizado a partir da definição de Roger Chartier $(1990,2002)$ como será especificado mais adiante.

${ }^{2}$ Sobre este termo, algumas conjecturas são possíveis. Como Maria Bueno foi morta na época da Revolta Federalista, popularmente conhecida como Revolta da Degola, por Ignácio José Diniz, que teria posteriormente se aliado aos Federalistas que sitiaram a cidade, tornando-se inimigos políticos dos Republicanos; após estes últimos retomarem a cidade, Maria Bueno foi tratada como mártir curitibano, uma vez que fora degolada por Diniz. Além disso, na década de 1940, foi publicado um livro que se propunha a ser uma espécie de hagiografia de Maria Bueno, no qual ela era retratada como uma personagem jovem, pura e casta que teria morrido em defesa de sua honra. Além disso, constatamos nas pesquisas de campo que para a maioria dos visitantes ela é associada a uma jovem, sendo, portanto retratada no diminutivo.
} 
sepulcros; e os santos mais populares acabaram ganhando construções maiores, os templos. Foi assim que surgiram as primeiras igrejas dedicadas aos santos. Portanto, historicamente falando, todo santo em seu primórdio era um santo de cemitério. Hoje em dia institucionalizados como Santos Padroeiros Locais.

A respeito da historicidade dos santos, descobrimos que os primeiros santos a serem cultuados foram os mártires e que a devoção por eles foi dada de maneira espontânea, como se o povo reconhecesse uma divindade naquele que sofre em nome de Cristo. Com o passar do tempo, porém, o conceito de mártir passou a abranger não apenas aqueles que davam a vida para defender a palavra de Cristo, mas também aqueles que morriam de forma violenta, provocada por homicídio ou doenças graves que causavam períodos prolongados de dor e sofrimento. O sofrimento na Terra representaria a redenção por seus pecados e, a morte, uma possibilidade de purificação (ANDRADE, 2010).

A Legenda Áurea, importante documento do século XIII, produzida por Jacopo de Varazze, é uma das coletâneas hagiográficas mais conhecidas e serviu de modelo para a escrita da vida de vários santos a partir da Idade Média. Ao trazer relatos de vidas virtuosas, a obra torna-se fundamental para o discurso hagiográfico.

Com efeito, nosso compilador ainda via os santos como pessoas cujas mortes, apesar de serem brutais, são acompanhadas por sons harmoniosos, pessoas cujos corpos torturados e mutilados emanam odor agradável, pessoas cujos restos mortais são imputrefatos e têm poderes taumatúrgicos que beneficiam a todos os que peregrinam até seu local de descanso e veneração. (FRANCO JÚNIOR, 2003, p. 16.)

Nesse sentido, o martírio parece ter sido elemento importante para a construção da santidade. O conceito de santidade, conforme alerta André Vauchez (1987), encontrase na maior parte das grandes religiões em que assume um significado ambivalente: evoca, de facto, algo de terrífico, que implica uma separação radical na condição humana, mas também a possibilidade de relação quanto ao divino, susceptível de efeitos purificadores.

Segundo Rudolf Otto (2007), a característica do santo é a de ser, ao mesmo tempo, totalmente diferente e extremamente próximo do homem. Não existiria para este 
autor uma religiosidade avançada que não tenha avançado também no compromisso e na exigência moral, entendidos como exigência da divindade. Ainda assim, pode existir um reconhecimento humilde do sanctum sem que seja tomado por exigências morais. Não se trata apenas de um receio diante do avassalador por excelência, perante o qual não resta nada senão a obediência cega e receosa. O que se exalta não é apenas poderoso por excelência, a exigir e impor seu poder, mas aquilo que em sua própria essência tem o direito supremo de reivindicar culto, ou seja, é exaltado pelo simples fato de ser digno de exaltação.

A ideia de que homens religiosos podiam participar da própria santidade da divindade e se beneficiar, pelo menos em certa medida, dos seus atributos, viria a conhecer um sucesso extraordinário nos primeiros séculos da cristandade. "A isso não é evidentemente estranha a difusão do cristianismo, uma vez que, desde os primeiros tempos da lgreja, a virgem, os apóstolos e finalmente os mártires - os testemunhos privilegiados de Cristo - foram considerados santos e venerados pela comunidade dos fiéis" ( VAUCHEZ, 1987, p. 288).

Ressaltamos a importância do martírio para a compreensão de Maria Bueno, pois, conforme indicado, os jornais da época de seu assassinato não a indicam como modelo de virtude, ao contrário, é descrita como aquela que atentaria ao pudor, fugindo às normas de boa conduta. Todavia, como perceberemos adiante, os discursos acerca de Maria Bueno vão se modificando, até que ela seja reconhecida como aquela que morreu em defesa da honra. Nesse sentido, a expiação pelo martírio, torna-se fundamental para a construção e legitimidade de sua santidade.

Nenhuma religião exprimiu de forma tão consumada, profunda e intensa o mistério da necessidade de expiação como o cristianismo. Também por essa razão, e principalmente por ela, evidencia-se sua superioridade sob outras formas de espiritualidade, e isto segundo critérios estritamente religiosos. Ele é mais religião, religião mais consumada que outras, na medida em que aquilo que religião implica nele se tornou actus purus. (OTTO, 2007, p. 95)

Refletir acerca da santidade de Maria Bueno implica considerar que sua legitimidade vem prioritariamente de seus devotos, uma vez que não é reconhecida 
enquanto santa pela instituição católica. Pensá-la, todavia, enquanto um santo não oficial, pode incorrer o risco de associá-la a uma prática religiosa menor, o que de forma alguma é intuito deste trabalho até porque a ótica que se privilegiou para pensar Maria Bueno e entender suas formas de representações é a dos próprios devotos. Nesse sentido, dentre os vários aportes teóricos possíveis, optou-se por partir do entendimento de Solange Ramos de Andrade acerca do que denominou "santo de cemitério" ao invés de "santo popular".

Ao historicizar o termo "santos populares", comumente utilizado para criar uma dicotomia entre os santos oficiais católicos e os santos não oficiais, é possível perceber que essa conceituação das manifestações populares no catolicismo coincide justamente com o período em que a Igreja percebe que está perdendo fiéis para tais práticas, seja para grupos dissonantes como a Umbanda, Espiritismo, Protestantismo ou mesmo para vertentes dentro de sua própria doutrina, como é o caso dos santos de cemitério.

É denominada religiosidade popular, a religião de massa latinoamericana, mais especificamente como sinônimo de catolicismo popular, o catolicismo dos santos, das procissões, dos rituais sem presença oficial. O olhar se volta exclusivamente para esse catolicismo que vai designar várias manifestações religiosas sempre com essa nomenclatura. (ANDRADE, 2008, p. 143-144)

A tentativa de incorporar tais práticas à Igreja, sob a nomenclatura de "popular", seria um modo encontrado pela Igreja de manter seus fiéis e ter controle dessas práticas para que não assumissem condições de ruptura.

Para mim, a Igreja Católica utiliza a acepção tradicional de tolerância, pautada na condescendência para as manifestações extraoficiais, caracterizadas como não lícitas, cuja proibição acarretaria inconvenientes de várias espécies. (ANDRADE, 2008, p. 153)

A partir do exposto, os conceitos de "estratégias" e "táticas" de Michel de Certeau (1998), nos auxiliam a pensar o culto a Maria Bueno sob a modalidade de "práticas instituídas". 
Chamo de estratégia o cálculo (ou a manipulação) das relações de forças que se torna possível a partir do momento em que um sujeito de querer e poder (uma empresa, um exército, uma cidade, uma instituição científica) pode ser isolado. A estratégia postula um lugar suscetível de ser circunscrito como algo próprio e ser a base de onde se podem gerir as relações com uma exterioridade de alvos ou ameaças (os clientes ou os concorrentes, os inimigos, o campo em torno da cidade, os objetivos e objetos de pesquisa etc.). Como na administração de empresas, toda racionalização "estratégica" procura em primeiro lugar distinguir de um "ambiente" um "próprio", isto é, o lugar do poder e do querer próprios. Gesto cartesiano, quem sabe: circunscrever um próprio num mundo enfeitiçado pelos poderes invisíveis do outro. Gesto da modernidade científica, política ou militar. (CERTEAU, 1998, p. 99)

Se as "estratégias" permitem à instituição católica a manutenção de uma certa unidade, ainda que sob o signo de tolerância, as "táticas", por sua vez, implicam a ausência de um próprio3, ou seja, “uma vitória do lugar sobre o tempo permite capitalizar vantagens conquistadas, preparar expansões futuras e obter assim para si uma independência em relação à variabilidade das circunstâncias." (CERTEAU, 1998, p. 99). Ou seja, nenhuma delimitação de fora lhe fornece a condição de autonomia.

A tática não tem por lugar senão o outro. E por isso deve jogar com o terreno que lhe é imposto tal como o organiza a lei de uma força estranha. Não tem meios para se manter em si mesma, a distância, numa posição recuada, de previsão e de convocação própria: a tática é movimento "dentro do campo de visão do inimigo", como dizia Von Büllow, e no espaço por ele controlado. Ela não tem, portanto, a possibilidade de dar a si mesma um projeto global nem de totalizar o adversário num espaço distinto, visível e objetivável. Ela opera golpe por golpe, lance por lance. Aproveita as "ocasiões" e delas depende, sem base para estocar benefícios, aumentar a propriedade e prever saídas. $\mathrm{O}$ que ela ganha não se conserva. Este não-lugar lhe permite sem dúvida mobilidade, mas numa docilidade aos azares do tempo, para captar no voo as possibilidades oferecidas por um instante. Tem que utilizar, vigilante, as falhas que as conjunturas particulares vão abrindo na vigilância do poder proprietário. Aí vai caçar. Cria ali surpresas. Consegue estar onde ninguém espera. É astúcia. (CERTEAU, 1998, p. 100)

3 Ou seja, "Uma vitória do lugar sobre o tempo permite capitalizar vantagens conquistadas, preparar expansões futuras e obter assim para si uma independência em relação à variabilidade das circunstâncias. É um domínio do tempo pela fundação de um lugar autônomo" (CERTEAU, 1998, p. 99). 
Pensar que a tática é a arte dos fracos, não significa entendê-los como vencidos, pois "quanto mais fracas as forças submetidas à direção estratégica, tanto mais esta estará sujeita à astúcia. Traduzindo: tanto mais se torna tática" (CERTEAU, 1998, p. 100). Reconhecer isto pressupõe entender a cultura enquanto prática instituída e instituinte, à medida que formaliza as práticas. É nesse sentido que se endossa a recusa pelo termo "santo popular’. A opção pelo termo "santo de cemitério" implica no reconhecimento das práticas individuais na formação das representações coletivas. Corrobora o entendimento de Michel de Certeau (1998), de que o que caracteriza a enunciação religiosa é a inscrição da experiência vivida numa linguagem, de forma a suscitar uma interpelação sobre a alteridade de sentido, demandando do sujeito crente um posicionarse e um agir.

\section{O caso Maria Bueno}

Jovem curitibana, "parda" e "pobre"4, essas são algumas descrições que encontramos referentes a Maria Bueno. Ela foi brutalmente assassinada por Ignácio José Diniz em um local próximo à atual Rua Vicente Machado, no centro de Curitiba. Dentre os vários relatos sobre o caso, conta-se que, no local de sua morte, foi colocada uma cruz de madeira e que o local teria se tornado um espaço de preces e devoções, onde devotos afirmavam ter seus pedidos atendidos por Maria Bueno. Conta-se ainda que um vizinha teria acendido uma vela no local do assassinato, a qual teria queimado por semanas sem se esgotar (SANTOS, 2010, p.68-69). Além dessas narrativas, há também a de que no local do assassinato teria surgido uma roseira de rosas vermelhas, o que faz com que, ainda hoje, muitos devotos homenageiem Maria Bueno levando rosas vermelhas ao seu túmulo, conforme detectamos nas pesquisas de campo.

A oralidade parece ter sido um dos fatores fundamentais para que se espalhassem as narrativas sobre as graças concedidas por Maria Bueno. Apenas em 1961, quando sua sepultura é transferida para um local de destaque no Cemitério São Francisco de Paula e, é construída uma capela em sua homenagem, esta se torna um novo espaço de devoção, recebendo um grande contingente de visitantes, no feriado de Finados.

\footnotetext{
${ }_{4}^{4}$ Essas descrições foram noticiadas no Jornal Diário do Comércio, no dia 30/01/1893, primeira notícia sobre a morte de Maria Bueno.
} 
O estudo das crenças e das devoções em torno de uma santa de cemitério não é necessariamente uma novidade nas Ciências Humanas ${ }^{5}$ no Brasil, e os trabalhos anteriores em muito contribuem para a compreensão de Maria Bueno. Maria Bueno morreu degolada vítima de Ignácio José Diniz. Este momento é muito importante à reflexão, pois é a partir dele que se abre um emaranhado de narrativas e explicações. 0 momento de sua morte seria, portanto, o que Mircea Eliade (1992) denominou "mito fundante", ou seja, o evento priorizado para a organização dos demais. As narrativas sobre o assassinato de Maria Bueno transitam entre a defesa da honra e a moça de "vida alegre"6.

Nos dias subsequentes, outros diários desta cidade, também informaram seus leitores acerca deste crime. Segundo o periódico A República, as autoridades policiais, tendo tomado conhecimento do fato, dirigiram-se ao local do crime e depois das primeiras investigações, transportaram o cadáver para o Hospital da Caridade onde se procedeu o exame de corpo de delito, verificando-se que a morte havia ocorrido "por uma quase decapitação". O Chefe de Polícia indiciou como responsável pelo crime, o anspeçada do $8^{\circ}$ Regimento de Cavalaria, o paraibano Ignácio José Diniz, que estando de guarda no quartel, teria fugido logo após a meia noite, apresentando-se por volta das quatro horas da manhã, para render guarda. O praça, segundo o jornal, estava "amasiado com a infeliz Maria e com ela queria casar-se ultimamente" (A REPÚBLICA, 01.02.1893, pp. 3). $O$ jornal A Federação naquele mesmo primeiro de fevereiro, informou os acontecimentos a seus leitores de forma lacônica, mas concluiu que "um crime tal, nunca foi visto nestas plagas". A investigação em torno destas fontes revelou que, apesar de ter se antecipado em relação aos seus concorrentes, na divulgação do assassinato, o Diário do Comércio não retornou mais a este assunto, o mesmo acontecendo com a Federação. Diferentemente, o diário A República, ao longo do processo jurídico acompanhou, passo a passo, o desenrolar dos acontecimentos, enfatizando o grande interesse dos leitores nas investigações e na prisão do acusado, especialmente por causa dos requintes de crueldade usados

\footnotetext{
5 Para aprofundar o conhecimento sobre os santos de cemitério no Brasil, sugere-se a leitura de ANDRADE, Solange Ramos de. Um estudo de religiosidade popular: O santo Menino da Tábua, 1994. ANDRADE, Solange Ramos de; SERAFIM, Vanda Fortuna. A religiosidade católica e seus santos: o Cemitério Municipal de Maringá - PR como espaço de devoção, 2010; CAVA, Ralph Della. Milagre em Joaseiro, 1976; GAÊTA, Maria Aparecida Junqueira da Veiga. Corpo santo, alma santa: o culto e a devoção à Menina Izildinha em Monte Alto (1950-1997), 1999; GRASSI, Clarissa. Um olhar... A arte no silêncio, 2006; JURKEVICS, Vera Irene. Os santos da igreja e os santos do povo: devoções e manifestações de religiosidade popular, 2004; KOSTER, Julia Impéria. A construção de uma santidade popular e os direitos da mulher, 2011; LIMA, Andrea de Alvarenga. A saga de Maria Bueno: um retrato da alma de Curitiba, 2007; REIS, Martha dos. Iracema, a Santinha de Marília - Um estudo sobre a criação de um imaginário popular, 1993; STOLL, Sandra Jaqueline; SANTOS, Conceição dos; BRAGA, Geslline Giovana; DURANDO, Vanessa Maria Bueno: Santa de Casa, 2011.

${ }^{6}$ Ver DIÁRIO DO COMÉRCIO, 30.01.1893. pp. 8.
} 
pelo suposto assassino. Transcorrido pouco mais de um mês do crime, esta gazeta afirmava ter sido concluído o inquérito policial que apontava como principal suspeito, Ignácio José Diniz e noticiava que o julgamento estava marcado para o próximo mês de julho. Segundo o articulista, "a fera nega a autoria do crime, embora todas as provas o apontem como o único responsável". O álibi apontado pelo réu era de que, naquela noite, encontrava-se de guarda na caserna. Demonstrando descrer dessa afirmativa, o jornalista encerrou seus comentários lançando uma pergunta intrigante: "e o encontro daquele macabro embrulho, no poço d'água do quartel?” (A REPÚBLICA, 02.03.1893, pp. 4). (JURKEVICS, 2004, p. 154-155)

É interessante observar que Diniz também aparece como "amásio” de Maria Bueno, pois essas narrativas de época tendem a apresentá-la como responsável por sua morte, uma vez que tinha atitudes inadequadas para uma moça da sociedade oitocentista: sem família, namoradeira e que gostava de dançar. De todo modo, o crime abalou a pequena Curitiba da época. Diniz foi preso e levado a julgamento, mas foi absolvido devido seu álibi, por constar como em serviço no quartel e ninguém ter testemunhado sua ausência. O que então gerou grande indignação popular?

Euclides Bandeira (1939), um dos memorialistas de Maria Bueno, escreveu que durante a Revolução Federalista, Diniz, então fora do Exército, foi apanhado com uma mula roubada. Preso, teria sido sumariamente fuzilado pelos federalistas, o que na voz do povo passou a representar um castigo divino. Embora, não exista comprovação do fato narrado, este, associado ao evento da morte violenta, possibilitou a existência do processo inverso, no qual os defensores de Maria Bueno, afirmam que, na verdade, a jovem teria morrido defendendo sua honra e virgindade de um algoz terrível, que não teria aceitado sua recusa para o sexo. Essa ideia pode ser verificada na oração a Maria Bueno, que é distribuída impressa pelos zeladores do túmulo no dia de Finados:

Na cruz, Jesus foi sacrificado...e vós...na cruz não fostes sacrificada, mas fostes sim, sacrificada sem o vereditum de um tribunal, por um algoz terrível, pior ainda que Judas. Apenas raiva o dia 29 de janeiro de 1893, quando o silêncio era profundo nesta cidade de Curitiba. Vós, quando a

\footnotetext{
7 Vide os jornais: FEDERAÇÃO, A: 01.02.1893; REPÚBLICA, A: 01.02.1893; 02.03.1893; 14.07.1893. Os jornais foram consultados no Arquivo da Biblioteca Pública do Paraná. Os documentos específicos sobre o momento da morte de Maria Bueno são as narrativas nos jornais aqui apresentados, o processo posterior perpassa por narrativas orais, que os fiéis atuais afirmam terem ouvido de seus pais, avós ou conhecidos.
} 
vida sorria cheia de alegria e esperança, recebias como Jesus, o amargor da traição, recebia na vossa inocência o bilhete falso de sentença da morte... na emboscada da encruzilhada daquela madrugada, vós morreste, morreste implorando ao Pai misericórdia. O Pai vos chamou, o povo chorou e vos santificou. Hoje o chão do céu pisas, mas em nossos corações ainda vives. E daqui ao Pai nosso Deus rogamos...dai a nossa protetora Maria da Conceição Bueno, força e poder...para que ela com sua imaculada bondade, possa cada vez mais e mais ajudar a todos aqueles que a vós imploram. Maria da Conceição Bueno, nossa protetora, nós vos agradecemos pelas milhares de graças que nos tendes concedido, e com a mesma fé que vós, em preces, rogava a vossa madrinha, Nossa Senhora da Conceição, nós a vós rogamos...olhai por nós...olhai pelos que sofrem...olhai pelos que imploram...olhai pelas criancinhas...olhai pelos doentes...olhai pela vossa irmandade...olhai pela vossa pátria...olhai por todos...que assim seja...em nome do Pai, do Filho e do Espírito Santo, amém ${ }^{8}$.

Se nos jornais curitibanos do final do século XIX, era "representada" como de condutada desviante, portanto responsável pela morte violenta que sofreu, em meados do século XX, esta percepção começa a se alterar. O romance Maria Bueno (1948), de Sebastião Izidoro Pereira, aqui tomado como fonte histórica, contribuiu para moldar a aura de santa de Maria Bueno. Problematizar o livro de Pereira é importante por ter sido a primeira fonte impressa, mais abrangente, sobre ela. E a primeira, também, que cita com riquezas de detalhes a sua figura de como uma santa. Além disso, muito do imaginário criado em torno de dela está presente nessa obra. A devoção em si aos poucos foi instaurada, mas a obra de Pereira contribuiu para a divulgação da figura mítica e também para o preenchimento de lacunas; em seu romance, partes da vida de Maria Bueno que pareciam obscuras ou totalmente confusas foram ganhando forma. Se os relatos contidos no livro realmente aconteceram na vida de Maria Bueno, não se saberá, mas o que importa aqui é perceber como se dá a construção de um mito.

Para que se entenda como se apresenta a descrição da santa Maria Bueno, que desde seu nascimento parecia destinada ao sagrado, será transcrito parte do relato de Sebastiana Garcia, que dizia ter conhecido Maria Bueno enquanto jovem e ouvido da boca de Maria esta história. Este relato está presente no livro Maria Bueno, de Sebastião Izidoro

\footnotetext{
${ }^{8}$ Essa oração é distribuída gratuitamente aos visitantes do túmulo no dia de Finados, impressa em um papel sulfite pelos cuidadores do túmulo.
} 
Pereira, e o autor afirma ter colhido este depoimento de linguagem simples e o traduzido tal como ele foi dito, sem acrescentar exageros de adjetivos por sua conta.

Era uma moça muito bonita, uma cabocla e tanto. Os pais dela chamavam-se Pedro e Julia. Tinha ela mais três irmãs que casaram e sumiram. Quando ela nasceu o pai ficou odiando a filha e tomou um pileque no dia que a viu, dois dias depois que chegou de uma viagem. Nesse dia ele quis dar com uma garrafa numa amiga da mãe dela e não pode porque um relâmpago fortíssimo o prostrou por terra no quarto, onde ficou dormindo embriagado. A mãe de Maria Bueno um dia antes de Ihe dar a luz, sonhou que viu Nossa Senhora da Conceição que the disse: "Essa menina vai cumprir uma missão na Terra". (PEREIRA, 1948, p. 17)

É possível perceber na citação acima, ainda que seja apenas um fragmento do relato original, a construção mítica de Maria Bueno na fala de Sebastiana Garcia, de que um dia antes de dar à luz Maria Bueno, sua mãe teria sonhado com Nossa Senhora da Conceição, a qual Ihe teria dito que a filha iria cumprir uma missão na Terra, fica clara a alusão à Virgem Maria. Tal como a mãe de Jesus recebeu o aviso de um anjo da luz, de que carregaria no ventre o filho de Deus, dona Julia, mãe de Maria Bueno, também recebeu de uma santa tal prenúncio de sacralidade. É uma tentativa efetiva - não quer dizer intencional ou ainda mal-intencionada - de ligar Maria Bueno ao catolicismo institucional em que santos já nascem predestinados a serem santos e a viverem em santidade.

As premissas do nascimento se repetem nos momentos que antecedem a morte:

Um dia antes de Maria ser morta ela ainda falou comigo quando se dirigia para casa onde ela ia fazer uns doces para uma pequena festa. Eu só soube da morte dela no dia seguinte ao meio dia. Não fui vê-la porque não tive coragem. Fiquei muito penalizada com a morte dela. Mas depois descobriram o criminoso, que era um soldado do Oitavo Regimento. Mas tarde ele foi solto pelo Gumercindo que soltou os presos quando entrou na cidade. Mas o soldado também foi fuzilado pelo mesmo Gumercindo. Eu soube disso e fiquei contente, porque Deus castigava o bandido que havia morto a minha amiga Maria Bueno. (PEREIRA, 1948, p. 19)

Izidoro Pereira destaca, ainda, que Maria Bueno apenas se dirigia às festas para fazer doces, sublinhando neste relato, que a festa, para ela, era apenas uma 
oportunidade de trabalho, realizado por uma mulher prendada. Em momento algum é mencionado que Maria Bueno frequentava festas, nem seu suposto envolvimento com Ignácio Diniz. É a vida santa que se procurava em Maria Bueno. O fuzilamento de Ignácio Diniz é também evocado como um castigo divino pelo assassinato de Maria Bueno. Aqui está clara a intervenção divina para castigar aquele que ousou matar uma santa. Entendese que na vida de Maria Bueno havia um sentido maior que guiava todos os acontecimentos. Ela deveria se entregar ao martírio, porém o algoz tinha que ser punido no final, senão qual o sentido do sofrimento?

Como é possível notar, tudo converge para o momento em que Maria Bueno se livraria de sua existência carnal para assumir de vez o papel para o qual sempre foi destinada: ser uma santa. O prelúdio de seu nascimento. A infância sofrida e o fato de ser órfã - recorrente em muitos mitos de mártires. A negação de colaborar com um adultério. O namoro casto e a vida humilde carregada de trabalho. O clamor por Deus. E, por fim, a morte trágica para preservar sua virgindade.

Para a compreensão da construção mítica de Maria Bueno, é de grande valia o estudo realizado por Vera Irene Jurkevicks, Os santos da igreja e os santos do povo: devoções e manifestações de religiosidade popular (2004), por apresentar uma versão mais mundana da história de Maria Bueno - em contraponto com a visão de Sebastião Izidoro Pereira. Segundo a autora, Maria Bueno era uma mulher das classes subalternas da sociedade recém-republicana de Curitiba, era parda - ao contrário de sua figura alva, mais comumente retratada - e por causa da origem humilde e de costumes pouco convencionais para época, era considerada uma cidadã de segunda classe; portanto, vista mais como uma causadora do que como vítima da própria desgraça.

Compreender o processo de construção da personagem pela devoção é tão instigante quanto reconstruir sua biografia - afirma Sandra Jacqueline Stoll, no livro Maria Bueno: Santa de Casa (2011). Um das percepções presentes nesta obra é de que haveria uma "relação horizontal" que os devotos estabelecem com os santos, ou seja, a leitura de uma vida impura de Maria Bueno, purificada com sua morte, apresenta uma existência mais mundana, que a aproxima de seus devotos e institui a possibilidade de salvação. 
Andréa Alvarenga de Lima, em A saga de Maria Bueno: um retrato da alma de Curitiba (2007), atenta à presença dos mitos dentro da religião moderna e suas nuances psicológicas. Ao preocupar-se com fatores mentais que criam mitos, demonstra como uma história aparentemente comum pode conter várias nuances mitológicas em sua própria forma de ser e, também, como outras nuances podem ser acrescidas de acordo com a "necessidade" de se criar um personagem mítico. Na narrativa de Maria Bueno, encontraremos várias imagens arquetípicas mescladas a um fato histórico, constituindo um enredo do herói da saga local, que é uma figura humana concreta, com sentimentos e ambiguidades. E é nesse conceito de "saga do herói” que Maria Bueno se insere enquanto um ícone feminista regional e atemporal.

Solange Ramos de Andrade dialoga com a criação do mito Maria Bueno no artigo "O culto aos santos: a religiosidade católica e seu hibridismo" (2010), demonstrando a redenção pelo martírio da morte como um dos elementos, talvez o principal em se tratando de catolicismo, que pode "levar um indivíduo para o reino de seu Criador". Nas palavras de Andrade, Maria Bueno, a santa de cemitério, dialoga perfeitamente com o tema martírio como forma de expiação dos pecados ao ter seu desenlace precedido por tamanho sofrimento: nos relatos da perícia da época, o corpo encontrado é descrito com fundos cortes nas mãos, que indicam que a vítima lutou muito para não ser morta, além do golpe a navalhadas no pescoço, que quase separou sua cabeça do corpo.

No parágrafo acima, percebemos que Maria Bueno já não é mais a 'mulher de vida alegre', mas aquela que morreu em defesa de sua honra. Convém destacar que, a partir do viés da História Cultural, a santidade de Maria Bueno não está sendo colocada em questão mais do que perceber os processos que permitiram que ela se tornasse uma santa de cemitério, os quais não são passíveis de serem organizados de forma cronológica pela historiografia, uma vez que implicam leituras, visões de mundo e atribuições de sentidos distintos e contraditórios à realidade. O intuito é perceber como, ainda hoje, mantém-se a devoção e a fé na realização de graças por Maria Bueno.

Embora Maria Bueno seja representada em outras religiões, como a Umbanda e o Espiritismo, no cemitério, espaço que analisamos, a representação que se sobressai é a Católica, aproximando-a de Nossa Senhora. Expostos os pressupostos instaurados pela 
nossa fonte, o romance Maria Bueno (1948), de Sebastião Izidoro Pereira, e as análises bibliográficas específicas sobre a temática, convém destacar que a nossa análise, não se volta à construção biográfica de Maria Bueno, seja por meio do romance ou das notícias de jornais. Embora não se abdique destas premissas, o estudo volta-se para a compreensão da prática religiosa por meio do estudo das devoções e crenças presentes entre os devotos que visitam o túmulo de Maria Bueno, no Cemitério São Francisco de Paula, no Dia de Finados, em Curitiba-PR. Por meio de questionários aplicados àqueles que visitam o túmulo, busca-se compreender mais a fundo a devoção a Maria Bueno na atualidade. A metodologia utilizada, dessa maneira, consiste na articulação entre a pesquisa documental, bibliográfica e a prática da pesquisa de campo (realizadas no Dia Finados no Cemitério Municipal de Curitiba, em 2013).

\section{A devoção a Maria Bueno}

De acordo com Clarissa Grassi, autora de Um olhar... A arte no silêncio (2006), em 150 anos de existência, o Cemitério Municipal São Francisco de Paula - o mais antigo de Curitiba - somou um vasto acervo de esculturas e manifestações artísticas. Mais do que ornamentação de túmulos, essas obras de arte traduzem as transformações históricas de Curitiba, assim como simbolizam a visão da população acerca da morte, expressa através da arte tumular. O cemitério é um museu a céu aberto. Podemos entender o ciclo econômico e migratório da cidade. A ornamentação e materiais utilizados nos túmulos permitem perceber o que era moda em diferentes épocas e ainda acompanhar a tendência artística e arquitetônica através do tempo (GRASSI, 2006).

Entre os inúmeros ilustres enterrados no Municipal, uma figura se destaca por sua história: Maria Bueno, lápide de $n^{\circ}$. 3903, quadra 13, rua 4. Quem tiver a oportunidade de visitar este cemitério no Dia de Finados, poderá verificar quão venerada é a santa curitibana. O túmulo de Maria Bueno é repleto de centenas de placas de graças recebidas como se pode observar abaixo) e flores, principalmente rosas vermelhas. O cemitério São Francisco de Paula funciona como uma espécie de espelho da sociedade curitibana; basta um passeio para identificar os grandes mausoléus que evidenciam o poder de algumas 
famílias em contraposição a de outras lápides, que denotam a origem humilde de seus falecidos (GRASSI, 2006).

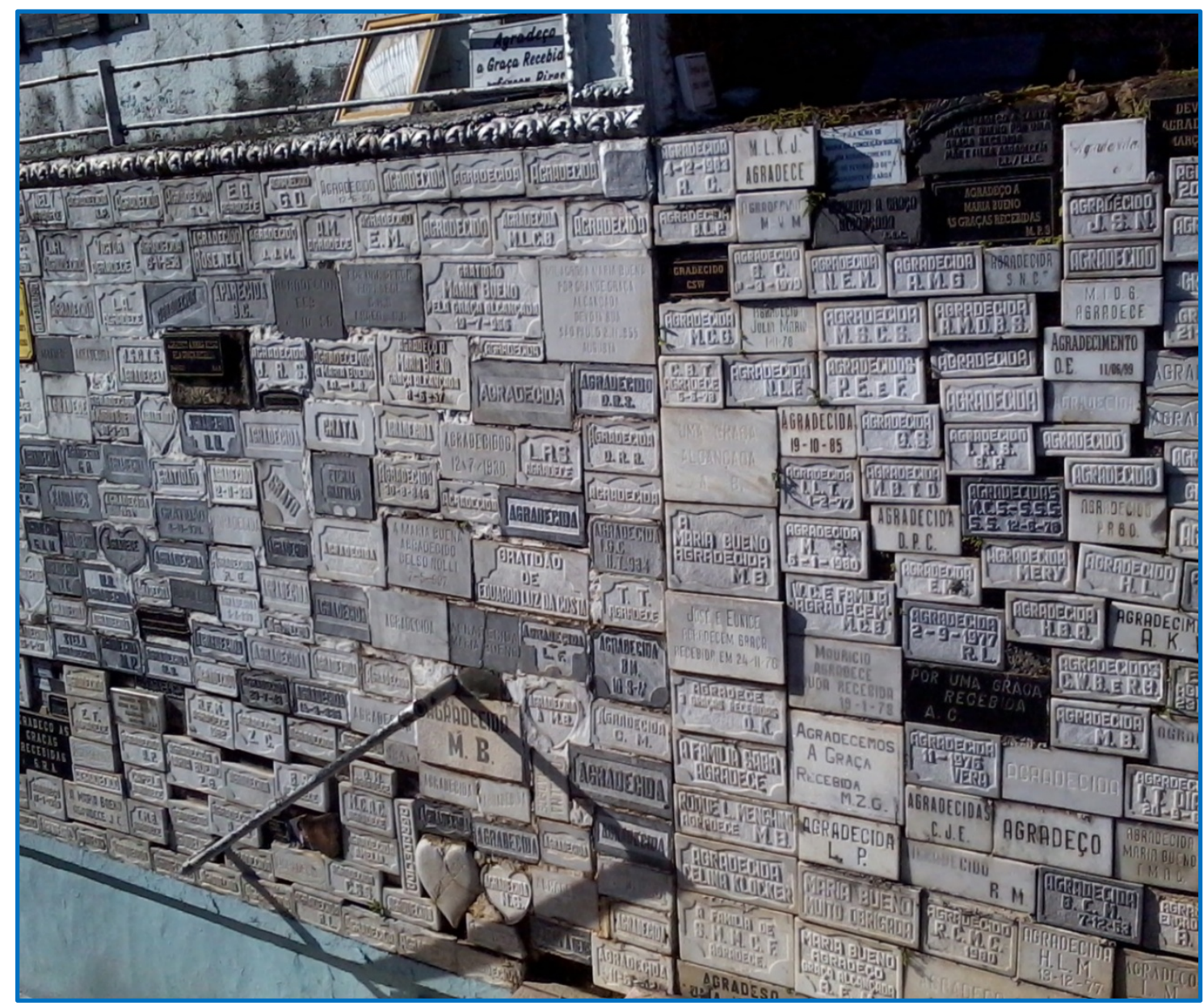

Imagem 1 - Ex-votos a Maria Bueno. A grande quantidade de ex-votos que Maria Bueno recebeu ao longo dos anos, fez com que muitas dessas placas tivessem que ser alocadas na parede à frente do túmulo.

Fonte: Arquivo LERR. 2013

A devoção a Maria Bueno, dispensando ou reduzindo significativamente as mediações institucionais, evidencia que o sagrado continua ocupando espaços que o homem e o mundo secularizado não conseguiram preencher. Contrariando as premissas do pensamento cientificista de que a fé seria vencida pela razão, uma ampla gama de atitudes espontâneas e populares, se sobrepõem às tentativas de normatização dos modos de crer proferidos pelas instituições religiosas e seus discursos oficiais. $O$ que encontramos, na prática, ao visitarmos o túmulo de Maria Bueno e observarmos as formas de crer e de devoção, é que estas se afastam de um pensamento uniforme ou 
igualmente assimilado pelos que recorrem a ela. Têm-se, ao contrário disto, múltiplas expressões de religiosidade e diversas nuances aparecem nas mais diversas leituras.

Para pensar o cemitério enquanto espaço de devoção, parte-se da obra O sagrado e o Profano, de Mircea Eliade (1992), que o entende como um espaço sacralizado, a partir da noção de Axis Mundi, simbolismo do Centro do Mundo. É ele que, na maior parte dos casos, nos permite entender o comportamento religioso em relação ao "espaço em que se vive". Ao instaurar e fundar um novo centro do universo que permite a comunicação é preciso considerar uma sequência de concepções religiosas e imagens cosmológicas que são solidárias e se articulam num "sistema", ao qual se pode chamar de "sistema do Mundo", envolvendo a compreensão de que um lugar sagrado constitui uma rotura na homogeneidade do espaço; essa rotura é simbolizada por uma "abertura", pela qual se tornou possível a passagem de uma região cósmica a outra; a comunicação com o Céu é expressa indiferentemente por certo número de imagens, referentes todas elas ao Axis Mundi (pilar, escada, montanha, árvore, cipó); e em torno desse eixo cósmico estende-se o "Mundo" ("nosso mundo") - logo, o eixo encontra-se "ao meio", no "umbigo da Terra", é o Centro do Mundo.

Como alerta Andrade (2008), ao tratar dos santos de cemitério, o espaço central dessa devoção, o altar desse santuário, é o seu túmulo que recebe uma multidão de fiéis durante o ano todo. Contudo, é no dia do aniversário de sua morte ou no Dia de Finados, que a presença dos fiéis se torna maior. Como forma de devoção, as pessoas que o visitam acendem velas, fazem pedidos, deixam mensagens de agradecimentos pelo milagre recebido e rezam. Se o santo tiver uma capela ou uma sala de milagres, são deixados ex-votos (objetos em gesso ou cera representando a parte do corpo curada, fotografias e outros objetos), que representam a efetivação do milagre alcançado. No caso de Maria Bueno, encontra-se um muro repleto de placas votivas, de agradecimento, confirmando a crença na realização do milagre.

Nesse sentido, a pesquisa de campo e a observação participante tornam-se fundamentais, pois, como indica Carlos Rodrigues Brandão (1985), elas foram “inventadas” como metodologias não a partir da lógica do sujeito pesquisador, ou de sua ciência, mas da própria cultura que investiga, tal como expressam os próprios sujeitos 
que a vivem. Considerando o uso de aplicação de questionários, convém ressaltar que se tem em mente que "o formato mesmo do questionário, elaborado unilateralmente pelo pesquisador, bloqueia o surgimento de dados novos e inesperados" (BRANDÃO, 1985, p. 29-30). Da mesma forma que quanto mais nos fechamos dentro de um quadro teórico rígido, mais veremos as respostas se limitarem a confirmar ou desmentir as hipóteses iniciais sem, contudo, abrir brechas ou espaços para a elaboração de outras hipóteses. É em virtude deste entendimento, que o questionário contemplou a possibilidade de resposta abertas e livres, ou seja, além de dar opções de resposta a quem responde o questionário, contemplam-se opções como: "Para você, Maria Bueno significa...". Ao partir desta técnica mais livre se "estimula a livre expressão da pessoa com quem se conversa, amplia o campo do discurso" (BRANDÃO, 1985, p. 30).

O estudo das crenças e manifestações religiosas, neste sentido, passa agora a considerar a experiência religiosa. Conforme explica Eliade (1992), o homem toma conhecimento do sagrado porque este se manifesta, se mostra como algo absolutamente diferente do profano. É sempre perigoso, mas também desafiante, buscar conhecer as representações sociais por meio das falas dos devotos. Mas, como indica Wilfred Cantwell Smith, “o estudo de uma religião é o estudo de pessoas” (1967, p. 57). Afinal, como tecer afirmações acerca de uma crença religiosa se os crentes não se reconhecem nela? "Uma forma de se descobrir o significado que algo tem para uma pessoa é perguntar a ela mesma", explica Smith (1967, p. 63). A transformação na forma como Maria Bueno é representada de finais do século XIX e, posteriormente, em meados do século XX, é ainda mais ampla e evidente no início do século XXI.

Partir do modo como os devotos vivenciam Maria Bueno ao prestar homenagens em seu túmulo, no Dia de Finados, é uma escolha metodológica que preza pelas visões de mundos. Os depoimentos e observações realizados não configuram, nem pretendem esgotar a devoção à santa como um todo, apenas contribuir para a compreensão dessa devoção, que é histórica e humana. Se as falas dos devotos podem por vezes parecer caricaturais, isto é porque, como alerta Saez (1996, p. 13), "a caricatura - como a antropologia - pode não mostrar como o rosto é na realidade; mas deve sempre mostrar o que diferencia esse rosto de qualquer outro" Mesmo com o risco de soar miscelâneo, 
digressivo e até contraditório, entendem-se tais aspectos como preciosos à compreensão da religiosidade que se estabelece em torno de Maria Bueno, na atualidade.

Nesse sentido, acompanhamos todo o dia de romaria, da hora em que a capela de Maria Bueno estava sendo aberta, até o momento em que foi fechada por seus guardiões. Eles são voluntários e devotos que prestam sua homenagem à santa com o trabalho de receber outros fiéis, orientá-los e vender souvenires que terão seu lucro revertido na melhoria e manutenção da própria capela, além de permitir a confecção de santinhos e fitas que são distribuídos gratuitamente no local. Atentemos a algumas percepções possíveis por meio da pesquisa realizada.

"Ela se parece com a Nossa Senhora", diz uma devota convencida de que essa comparação é uma grande homenagem. As características da imagem de fato, a pele alva, a túnica branca e o manto azul, se assemelham às representações da Virgem Maria. Se o ritual no cemitério se configura como a manifestação física da religiosidade católica na qual Maria Bueno se insere, é possível compreender que o cemitério, como local de devoção, intensifica a relação imediata dos devotos com a santa Maria Bueno. Eles têm em suas mãos todos os elementos da devoção; não há dogmas nem intermediários, cada devoto decide como será sua relação com "sua" santa, isso dá a autonomia e a liberdade que em uma religião oficial o devoto não encontraria.

Supõe uma clara distinção entre o que representa e o que é representação, o que nesse caso, seria instrumento de um conhecimento mediato que revela um objeto ausente substituindo-o por uma imagem capaz de trazê-lo à memória e pintá-lo tal como é. (ANDRADE e SERAFIM, 2010, p. 125)

Desta maneira, o cemitério é um espaço devocional não apenas como uma forma física de relação entre os devotos e Maria Bueno, mas como um espaço transcendente onde o sagrado se manifesta através de imagens, orações e principalmente da figura do túmulo como altar.

Pensar Maria Bueno, todavia, como símbolo exclusivo de uma religiosidade católica seria realizar uma simplificação mutiladora e que negaria as interpretações dos devotos. "Você sabe que a Maria Bueno não era assim como a gente está vendo?", indagou- 
nos um devoto durante a pesquisa de campo ocorrida no Dia de Finados de 2013. Ao nos observar aplicando questionários, ele parecia intrigado com o que seria escrito sobre Maria Bueno. Em tom de quem segreda algo muito importante e ao mesmo tempo censura, foi construída a indagação. Retribuímos com um “Assim como?”, denotando o mais profundo interesse. E ele responde "Branca, com essas roupas assim", e ainda completa: "Eu não a vejo do jeito que ela está ali”, referindo-se à estátua presente no santuário que constitui o túmulo de Maria Bueno.

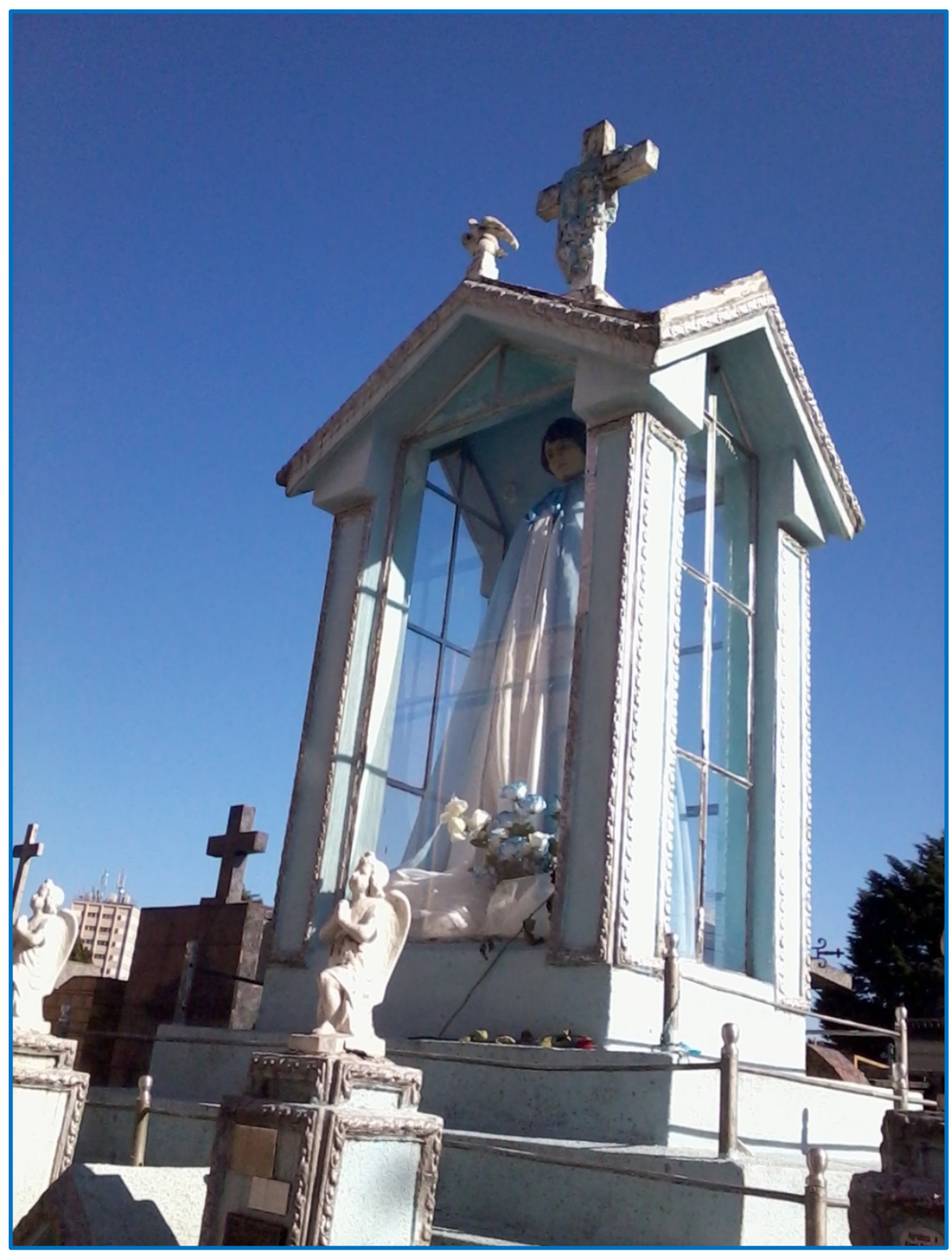

Imagem 2 - Imagem do túmulo de Maria Bueno. Fonte: Arquivo LERR. 2013. 
A fala do devoto adquire sentido na medida em que explica ser umbandista e afirma seguir a linha cruzada, da Umbanda com a Quimbanda; narra, inclusive, a respeito de uma graça que teria recebido de Maria Bueno, explicando que rezava para ela em outra língua, mas sem dizer qual. Prossegue afirmando que Maria Bueno poderia se manifestar enquanto a Pombagira (entidade da Umbanda) e que se déssemos uma volta completa à capela de Maria Bueno, quando estivéssemos indo embora, ela estaria olhando para nós. Essa afirmação em si carrega uma forte simbologia, pois segundo seu relato, Maria Bueno teria sido apunhalada pelas costas, logo, jamais daria às costas para quem roga por ela.

Outra história que nos chamou a atenção foi a de um engenheiro, devoto de Maria Bueno há muitos anos, que relatou que sua mãe há muito tempo esteve doente e nenhum médico encontrava a causa. Teriam, então, descoberto tratar-se de uma “obsessão espiritual”. E por meio da interseção de Maria Bueno, feita através de uma médium, sua mãe fora curada. Desde então, ele teria se tornado espírita e devoto de Maria Bueno. É recorrente a divulgação de centros espíritas em Curitiba que afirmam receberem Maria Bueno para aconselhamento espiritual.

Outra devota parou-nos na escada e afirmou, sem cerimônia, que "Maria Bueno é santa dos presidiários", como ela foi morta por um policial, explicou a devota, ela protege os presos e até ajuda, quem se comporta e se arrepende a sair da cadeia. Outra representação mais recente de Maria Bueno foi a utilização de sua imagem na "Marcha das Vadias", em Curitiba, em 2011. Entender como Maria Bueno se torna um símbolo feminista na atualidade, por meio do conceito da saga do herói e da redenção pelo martírio da morte, pressupõe que Maria Bueno constitui em si duas representações, a da santa e a da prostituta (LIMA, 2007). Se, socialmente, estas parecem divergir, no âmbito das relações humanas são complementares por estarem vinculadas à uma terceira representação: a da mulher, do feminino. 


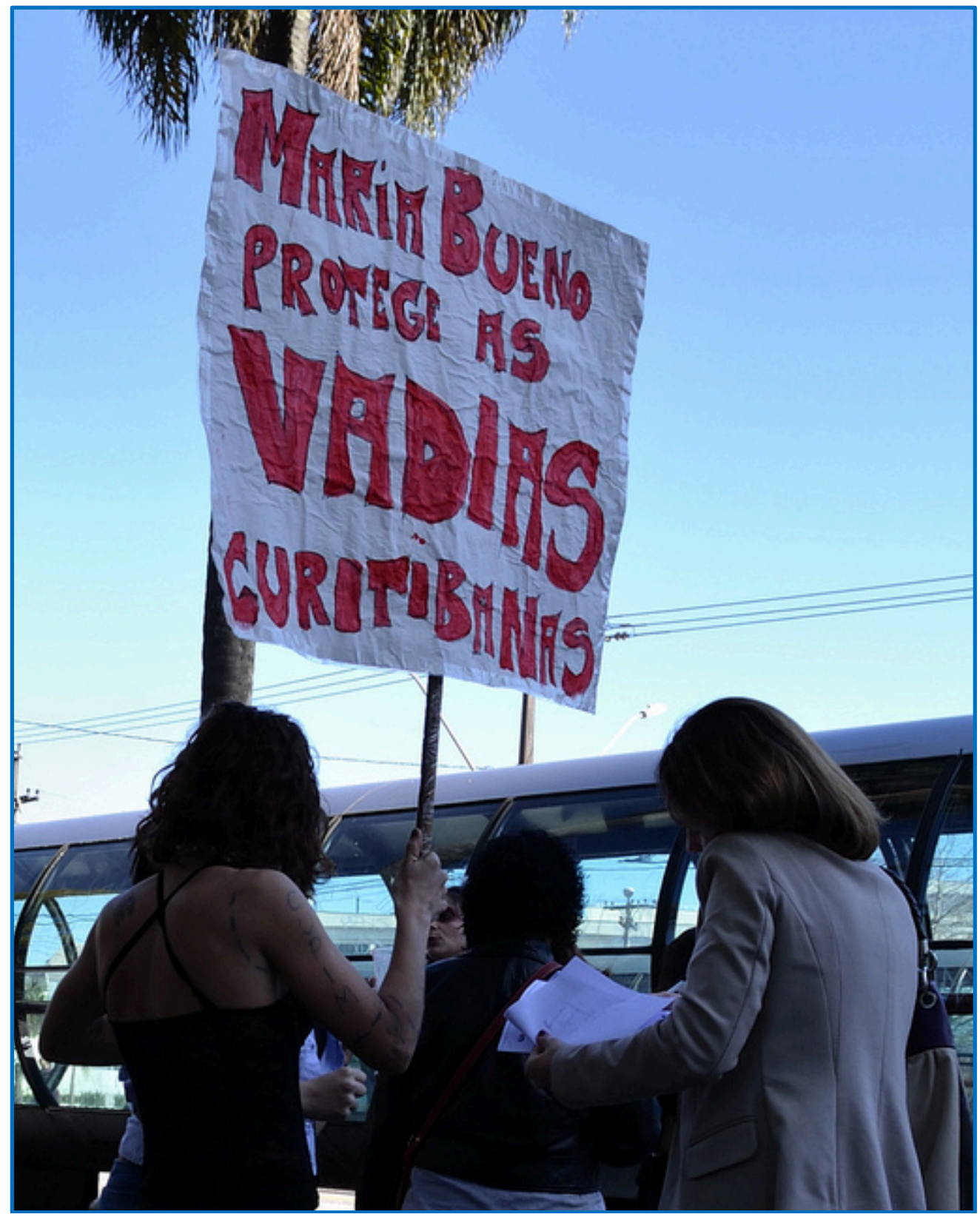

Imagem 3 - Imagem de cartaz em referência a Marcha das Vadias em Curitiba, 2011. Disponível em: <http://forum.mundofotografico.com.br/index.php?topic=59832.0 > Consulta: 24 Fev. 2014

Ao iniciarmos esta pesquisa, encontramos primeiramente a narrativa sobre a mulher que morre defendendo sua honra e que, como consequência de seu martírio mortuário, acaba elevada à santidade. Evidenciam-se, dessa forma, várias tentativas de sufocar o ímpeto feminino de Maria da Conceição Bueno. O mito que prevalece e congela a representação de Maria Bueno enquanto santa é o de uma mulher predestinada ao sagrado. Liberta, ou transcendendo, de sua mundanidade, Maria Bueno afasta-se de seus 
pecados e os maldizeres se esvanecem, tendo o seu caráter feminino, em parte, sido dissociado de sua figura. Pois, em se tratando de uma devoção não institucional, dentro da religiosidade católica, percebe-se a aproximação e apropriação da imagem de Maria Bueno enquanto santidades marianas tradicionais. O manto azul, sua expressão serena e mesmo a "forçada" alvura da pele fazem alusão à imagem de Nossa Senhora. Permanecese, assim, do feminino a mãe e a virgem.

Porém, considerando que as imagens são historicamente interpretadas, segundo os grupos que as leem e as interpretam, a figura de Maria Bueno assume um novo significado no século XXI. De santa, passa-se a dar foco a Maria da Conceição Bueno, enquanto mulher, marginalizada, vítima do preconceito e violência masculina. Percebemos desta maneira um processo inverso ao que possibilitou a imagem de santa. Se no processo de santificação, a trajetória de vida é ocultada deixando de lado o seu caráter mundano e profano para dar espaço a sua sacralidade, podemos identificar na atualidade uma inversão de valores que se atenta justamente à historicidade de Maria Bueno, seu caráter humano e sua relação com a sexualidade e com a dominação masculina.

Maria Bueno virou cartaz na Marcha das Vadias de Curitiba em 2011, movimento feminista que luta pela liberdade sexual feminina e pela não violência contra as mulheres. O fato de ser conhecida também como a Santa Prostituta ${ }^{9}$, o caráter ousado e libertário que se atribui a ela, com certeza são argumentos de peso para que seja alçada à condição de "feminista de seu tempo". Colocamos entre aspas, com o cuidado de uma pesquisa acadêmica histórica não se tornar anacrônica, pois feminismo é um termo cunhado em fins dos anos 1960, mas neste contexto passaria a significação de mulheres que de alguma forma - mesmo que não intencional como no caso de Maria Bueno, que pagou com a vida por suas escolhas - representassem a liberdade do feminino.

Apesar das distintas leituras, o que prevalece são as pessoas que vieram ao túmulo agradecer ou pedir por seus familiares, um alívio para dor ou para o coração, uma chance de um emprego melhor, enfim, cada devoto procurava em seu íntimo algo na santa que possibilitasse uma identificação por meio da dor. O processo de identificação, em casos

\footnotetext{
9 Segundo o Diário do Comércio de 30 de janeiro de 1893, Maria Bueno era "uma dessas pobres mulheres de vida alegre", (um eufemismo para prostituta) e fora assassinada a navalhadas numa cena de ciúmes.
} 
de devoção popular como é a prestada a Maria Bueno, é a principal força motriz da fé.

Essa leitura nos permite também entender as dinâmicas sociais, pois ao indagarmos aos devotos o que pensavam de Maria Bueno ser vista como uma prostituta, ao invés de vermos expressões escandalizadas ou mesmo ofendidas por compararmos sua santa de devoção com uma meretriz, tivemos a surpresa da passividade e condolência com a vida pouco convencional de Maria Bueno. Alguns devotos relatavam que Maria Bueno havia sido abusada na adolescência, portanto justificaria seu comportamento pouco usual. Outros viam nela apenas uma liberdade maior, sem enxergar problemas nisso, como faziam as gerações passada. Sinal de mudança nos conceitos do que significa viver em santidade. Apesar da permissividade para com as escolhas sexuais da santa, a maioria dos devotos não a vê como símbolo feminista, apenas como uma mulher que batalhou e sofreu por escolher, ou ter o azar de encontrar, homens errados no seu caminho.

\section{Maria Bueno e suas representações}

Os relatos acima foram eleitos com o intuito de identificar o modo como, em diferentes lugares e momentos, uma determinada realidade social, no caso em tela, Maria Bueno, é construída, pensada e dada a ler (CHARTIER, 1990). Viemos até aqui utilizando o termo representação em diversos momentos. Convém ressaltar que a opção pelo conceito de representação nos permite articular três modalidades de relação com o mundo social: Primeiro, o trabalho de classificação e de delimitação que produz as configurações intelectuais múltiplas, através das quais a realidade é contraditoriamente construída pelos diferentes grupos. Segundo, as práticas que visam fazer reconhecer uma identidade social, exibir uma maneira própria de estar no mundo, significam simbolicamente um estatuto e uma posição. E por fim, as formas institucionalizadas e objetivadas graças às quais uns representantes (instâncias coletivas ou pessoas singulares) marcam de forma visível e perpetuada a existência do grupo, por meio das séries de discursos que o apreendem e o estruturam, conduz obrigatoriamente a uma reflexão sobre o modo como uma figuração desse tipo pode ser apropriada pelos leitores dos textos (ou das imagens) que dão a ver e a pensar o real. (CHARTIER, 1990, 2002). 
Sobre os devotos de Maria Bueno, constatou-se, por meio da pesquisa de campo realizada no Cemitério São Francisco de Paula que, embora a devoção a Maria Bueno não seja exclusivamente feminina, com uma grande quantidade de homens visitando o túmulo para agradecer as graças alcançadas, fazer pedidos e homenageá-la, cerca de setenta por cento de seu público é constituído por mulheres. Convém destacar que, assim como as mulheres, os homens pareciam igualmente engajados e não apenas meros acompanhantes. O número de questionários aplicados na pesquisa não é tão extenso ${ }^{10}$, configura-se como uma amostragem para pensarmos as representações acerca de Maria Bueno.

A faixa etária dos devotos é mais reincidente na casa dos 50 anos, seguidas dos 30 e dos 40 anos. Embora haja variações entre as demais idades, os números são bem menores. A maioria dos devotos reside em Curitiba, sendo pouquíssimos de fora do estado, e visitam o cemitério no Dia de Finados anualmente, vindo em sua maioria por meio de automóveis, seguidos de transporte público e poucos a pé. A escolaridade dos devotos é prioritariamente o "Ensino Fundamental incompleto" e "Ensino Médio completo", embora existam pessoas com formação superior, inclusive com pósgraduação. Quando indagados sobre a religião, o catolicismo é a resposta mais obtida; alguns poucos se declararam espíritas, umbandistas, sem religião, evangélicos ou optaram por não responder, mas não totalizam vinte por cento.

Entre os devotos, encontramos profissões variadas como advogado, engenheiro, professor e jornalista; todavia, estes não chegaram a dez por cento das pessoas questionadas. A maioria delas consistia em mão de obra sem qualificação específica, como: pedreiro, artesão, porteiro, diarista, do lar, auxiliar de serviços gerais, empregada doméstica, costureira, vendedor, funcionário público, cozinheiro, promotor de vendas, assistente jurídico, eletricista, operário, auxiliar administrativo, restaurador de carros, montador, conferidor de estoque, agente de saúde, segurança e vendedor autônomo. Além dessas, havia alguns poucos estudantes, um empresário e um militar.

Uma das questões que fizemos aos devotos era sobre quais túmulos eles visitavam além do de Maria Bueno. Dos quarenta e três que responderam ao

\footnotetext{
10 Foram aplicados 43 questionários a partir dos quais foram colhidas as informações apresentadas no decorrer deste artigo.
} 
questionário, vinte e quatro vieram visitar exclusivamente o túmulo de Maria Bueno, sendo que treze visitaram também parentes, e três visitaram o túmulo de outra santa ${ }^{11}$. Muitos dos devotos já visitavam o túmulo de Maria Bueno há mais de cinco anos, e apenas oito visitavam pela primeira vez.

Dos entrevistados que responderam não visitar o túmulo pela primeira vez, vinte e uma pessoas afirmaram que visitam o túmulo de Maria Bueno apenas no Dia de Finados todos os anos. Apenas dez por cento da amostragem indicou visitar o túmulo frequentemente, com certa regularidade, e alguns poucos disseram que além do Dia de Finados, visitam ocasionalmente. Ao serem indagados a respeito do motivo da visita, as respostas variavam entre "porque é ela santa" em sua maioria, "para gradecer por graças alcançadas", "para pedir graças”, "por curiosidade”, “para acompanhar alguém”, “porque a Maria Bueno ajuda as pessoas", "pela história de vida comovente”, "pagar promessas”, “obter intercessões”, “por ser famosa”, “porque dá sorte”.

Como percebemos, os motivos pelos quais os visitantes buscam o túmulo de Maria Bueno são variados. Nesse sentido, Santos (2010) e Stoll (2011) explicam que conforme a urgência, o devoto recorre a mediadores situados em diferentes níveis da hierarquia celestial. É o que as autoras chamam de devoção horizontal. A devoção horizontal constitui a distancia espiritual que o santo se encontra do devoto. Por exemplo, se pensarmos na figura de Deus, este se encontra situado hierarquicamente acima dos demais santos, é longínquo. Já Maria Bueno, uma santa local apresenta uma existência mais mundana - portanto mais próxima do devoto -, ainda que seja uma figura sagrada parece haver uma aura de identificação e tolerância em Maria Bueno, como se ela ouvisse o devoto mais intimamente e fosse mais condescendeste com seus erros e aspirações; essa é a relação horizontal.

Quando questionados sobre o que Maria Bueno simbolizava para eles, as respostam consistiram, na ordem de maior reincidência, em: "Santa", "paz", "divino", "Nossa Senhora", "vida/esperança", "espiritismo", "proteção", "orgulho", "prosperidade", "folclore", "mulher", "sofrimento", "tudo", "superação". Como explicam

\footnotetext{
${ }^{11}$ Para finalidade deste artigo não será possível aprofundar, mas no Cemitério São Francisco de Paula há, além de Maria Bueno, o túmulo da Menina Eunice, ao lado do de Maria Bueno, que teria morrido aos sete anos de meningite.
} 
Santos (2010) e Stoll (2011), as razões que motivam a escolha de um santo podem se dar por herança familiar: o santo que já era cultuado pela avó da devota; a ligação com outro santo que o devoto já cultua; por indicação, quando o devoto se encontra aflito e tem o santo indicado por alguém que diz ser o santo propício para tal aflição; mas, principalmente, por identificação: o santo da cidade ou profissão do devoto, o agrado pelas ações do santo em vida ou se este viveu um drama parecido com que o devoto está vivendo no momento de aflição. Talvez essa seja a principal razão de Maria Bueno ser cultuada principalmente por mulheres de vida humilde e também pelas prostituas mulheres expostas constantemente à violência masculina.

As descrições sobre a história de Maria Bueno assumem referências múltiplas: "Foi assassinada por um policial/um militar", "Foi uma mulher guerreira", "Seu corpo não se decompôs", "Foi abusada pelos homens do exército", "Foi estuprada e morta por marginais", "Ela faz milagres", "Foi abusada na adolescência pelo patrão", "Foi degolada pelo companheiro", "Era uma prostituta", "Morreu defendendo sua virgindade", "Era uma pessoa boa quando viva", "Foi uma mártir", "Não era bem vista pela sociedade da época".

Essas histórias são, em sua maioria, ouvidas no âmbito familiar, seguidas por relatos de amigos e conhecidos, e em terceiro lugar pela mídia. Algumas poucas pessoas indicaram terem tomado conhecimento de Maria Bueno por meio de uma microssérie chamada Maria Bueno, produzida pela RPC TV, e exibida pela Rede Globo de televisão, no quadro Casos \& Causos, no ano de 2007. Outras mencionaram terem visto reportagens na televisão sobre o Dia de Finados em Curitiba e a previsão de túmulos mais visitados. Uma informação que não conseguimos confirmar seria a de uma radionovela transmitida por alguma rádio curitibana sobre Maria Bueno. Além de disso, houve indicações de conhecêla por meio da internet ou por centros espíritas em Curitiba.

As diferentes estórias sobre Maria Bueno colhidas entre os devotos confirmam a ideia de que o momento de sua morte remete ao "mito fundante" de Mircea Eliade (1992). Não importa significativamente por quem foi assassinada ou quais eram as suas atitudes antes deste evento. Importa apenas a morte violenta, evento priorizado para a organização dos demais.

Os motivos pelos quais os devotos recorrem a Maria Bueno, também são variados: 
prioritariamente a busca por questões relacionadas à saúde, seguida por conflitos familiares, a ajuda na obtenção de empregos, a dificuldade em relações amorosas, a busca por bens materiais, auxílio para lidar com dores e sofrimento e casos de violência. Uma das devotas relatou que recebeu o nome de Maria em seu batismo como forma de agradecimento à santa que teria auxiliado em seu nascimento. Segundo ela, além do parto difícil, enquanto bebê tivera muitos problemas de saúde, tendo sido Maria Bueno a responsável por sua melhora. Convém destacar também um jovem rapaz que, no ano de 2013, havia sofrido um acidente que lhe tirara a visão de um dos olhos e, ao conversar com ele, nos foi informado que o motivo da visita ao túmulo era pedir a graça de ter sua visão de volta. Recentemente, no Dia de Finados de 2015, encontramos o mesmo rapaz visitando o túmulo de Maria Bueno, completamente curado e agradecendo a ela pela graça concedida.

Nesse sentido, compartilhamos a opção teórica de Michel de Certeau (1998), ao afirmar que entende “[...] por 'crença' não o objeto do crer (um dogma, um programa etc.), mas o investimento das pessoas em uma proposição, o ato de enunciá-la considerando-a verdadeira - noutros termos, uma 'modalidade' da afirmação e não seu conteúdo". Ao partirmos da ótica dos sujeitos individuais que visitam o túmulo de Maria Bueno, é possível constatar que a multiplicidade de significados permite uma ampla devoção e adesão religiosa em torno da crença na santa.

Do mesmo modo, variam os significados que Maria Bueno assume para cada devoto: "É uma santa" afirma a maioria, "Faz parte da história de Curitiba", "Intercessora/Pessoa que ajuda", "Lembrança de minha mãe", "Paz/ Amor/ Carinho/ Bondadel Esperança", "Nasceu predestinada a ser santa", "Espírito elevado", "Nossa Senhora", "Alguém para se conhecer". Outro relato que nos chamou a atenção foi o de uma mulher loira, na casa dos quarenta anos, que após se aproximar, acender uma vela e fazer suas orações, nos contou que o motivo pelo qual visitava Maria Bueno era para pedir uma "revelação"; acreditava ela estar sendo traída pelo companheiro e queria que a santa ajudasse a desmascará-lo.

As motivações que justificam o culto aos santos são diversas. Segundo Alba Zaluar (1983), a devoção aos santos está carregada de aspectos práticos em detrimento aos 
aspectos formais; em toda localidade existe a devoção a algum santo, que é homenageado por meio de novenas, ladainhas, festas ou danças. Os santos mais poderosos têm seu dia de festa. É marcante a preocupação com a doença e os outros males aos quais se atribuem causas sobrenaturais. A decisão de recorrer aos diversos tipos de curadores existentes localmente parece decorrer de raciocínios mais ou menos integrados. O campo sob o domínio de Deus e dos santos não está necessariamente limitado às doenças. A ajuda dos santos é invocada para todos os acontecimentos em que existem elementos de incerteza e que escapam ao controle humano (ZALUAR, 1983).

Dessa maneira, observa-se que Maria Bueno é uma santa de cemitério de interfaces múltiplas e procurada por motivos diversos. Todavia, é fundamental destacar que o que mantém a sua devoção e prestígio são as graças concedidas, uma vez que atestam a força milagreira da santa. A observação in loco nos possibilita uma história social das interpretações remetidas para as suas determinações fundamentais (que são sociais, institucionais, culturais) e inscritas nas práticas específicas que as produzem. Conceder, deste modo, a atenção às condições e aos processos que, muito concretamente, determinam as operações de construção do sentido é reconhecer que as inteligências não são desencarnadas, e que as categorias aparentemente mais invariáveis devem ser construídas na descontinuidade das trajetórias históricas (ZALUAR, 1983).

As representações são distintas e múltiplas por remeterem a devotos que carregam em si particularidades, distintas "visões de mundo", ou seja, "conjunto de aspirações de sentimentos e de ideias que reúnem os membros de um mesmo grupo (de uma classe social, na maioria das vezes) e os opõem aos outros grupos". Ela permite fazer uma tripla operação: atribuir um significado e uma posição social aos textos literários e filosóficos; compreender os parentescos existentes entre obras de forma e natureza opostas e; discriminar no interior de uma obra individual os textos "essenciais", constituídos como um todo coerente, com o qual cada obra singular deve ser relacionada (CHARTIER, 1990).

A simbologia do que Maria Bueno denota para os seus devotos parece, por um lado, se afastar de disposições fixas de interpretação, não possuindo um caráter de obrigação específica para o seu conjunto de visitantes. Por outro lado, a devoção religiosa 
se assemelha à prática voluntária e pessoal, implicando em uma opção individual que mantém a primazia mesmo no caso em que a atividade assume uma forma coletiva. Para Danièle Hervieu-Léger (2008), o panorama religioso contemporâneo estaria marcado pela difusão do crer individualista, pela disjunção da crença e das pertenças individuais e pela diversificação das trajetórias percorridas pelos indivíduos, praticada de modo voluntário, autônomo, variável, individual, móvel e excepcional.

\section{Considerações finais}

Diante de objeto tão plural e em torno do qual se constitui um amplo emaranhado de narrativas, torna-se problemático optar por uma única explicação que organizaria todas estas representações. Nesse sentido, apenas no âmbito teórico é possível amarrar algumas explicações sem se pretender autoritárias em relação às subjetividades que movem os indivíduos que frequentam o túmulo de Maria Bueno.

O que presenciamos no Cemitério São Francisco de Paula no dia de Finados, em torno da devoção à Maria Bueno, parece convergir para o que Pierre Sanchis (2001) e Danièle Hervieu-Léger (2008) apontam como a emergência de novas formas de crenças no Brasil e a perda de força das instituições tradicionais na regulamentação da produção de sentido, indicando que as crenças se disseminam e conformam-se cada vez menos a modelos estabelecidos; há uma bricolagem de crenças, uma maior autonomia na dinâmica da construção dos sistemas de fé.

José Carlos Pereira, na obra Sincretismo religioso e ritos sacrificiais (2004) indica que é fundamental a relação da condição do devoto para a escolha do santo. Os devotos de Maria Bueno não formam uma massa homogênea. Encontram-se entre eles mais mulheres que homens, mas não podemos afirmar, em virtude disto, que Maria Bueno é uma santa exclusivamente feminina. Em questões de condição social, também vemos a heterogeneidade se manifestar. A condição em torno do qual se organiza a devoção é a de dor e sofrimento, por isso o martírio é um elemento tão importante.

De acordo com Pereira (2004), boa parte dos devotos que chegam aos santuários cujos santos são mártires, trazem também em seus corpos e sentimentos marcas de sofrimento e a esperança de superá-los. São os devotos, segundo o autor, também 
vitimados pelas mais variadas formas de violência, pobreza, fome, doenças, vícios, e toda sorte de tormenta que a condição humana lhes pode causar. Ora, é exatamente que observamos nas pesquisas de campo. Não é possível mensurar ou quantificar de que maneira as dores e as angústias são vividas por cada indivíduo, mas a importância social e cultural que Maria Bueno assume na vida de seus devotos, que a elegeram como símbolo de fé, esperança e de crença.

Por fim, o objetivo deste artigo foi o de tecer alguns apontamentos teóricos sobre as crenças religiosas no Paraná, a partir do caso de Maria Bueno, atentando às distintas formas de representação a ela atribuídas e à forma como atrai devotos até a atualidade. A pesquisa constatou que a prática devocional a Maria Bueno torna-se uma religiosidade com ritual próprio, cheio de símbolos bem particulares, símbolos estes, muitas vezes apropriados de outras religiões, mas que demonstram o estreito vínculo com as culturas e modos de ser e estar no mundo a partir do qual as práticas religiosas humanas se organizam.

\section{Referências}

A FEDERAÇÃO. Curitiba: s/ed.: 01.02.1893; 01.02.1893, p. 3; 02.03.1893, p. 2.

A REPÚBLICA. Curitiba: s/ed. 14.07.1893.

ANDRADE, Solange Ramos de. A religiosidade católica e a santidade do mártir. Projeto História, São Paulo, n.37, p. 237-260, dez. 2008. . Disponível em: <http://revistas.pucsp.br/index.php/revph/issue/view/201> Consulta: 31 Jan. 2014.

ANDRADE, Solange Ramos de; SERAFIM, Vanda Fortuna. A religiosidade católica e seus santos: o Cemitério Municipal de Maringá(PR) como espaço de devoção. História Agora. Ano VIII, v.10, 2010. p.103-136. Disponível em: <http://www.historiagora.com/revistasanteriores/historia-agora-no10/50-dossie/219-a-religiosidade-catolica-e-seus-santos-ocemiterio-municipal-de-maringa-pr-como-espaco-de-devocao> Consulta: 19 Ago. 2013.

ANDRADE, Solange Ramos de. O culto aos santos: a religiosidade católica e seu hibridismo. Revista Brasileira de História das Religiões. Ano III n. 7, p. 131-145, maio, 2010. Disponível em:< http://www.dhi.uem.br/gtreligiao> Consulta: 23 Mar. 2014.

ANDRADE, Solange Ramos de. Um estudo de religiosidade popular: o santo Menino da 
Tábua. 1994. Tese (Mestrado em História) - Universidade Estadual Paulista, Assis(SP), 1994.

BANDEIRA, Euclides. Maria Bueno. IN: Cronicas Locaes. Centro de Letras do Paraná. Tip. da Escola de A. Artifices: Curitiba/Paraná, 1941. p. 87-90.

BRANDÃO, Carlos Rodrigues. Repensando a pesquisa participante. 2.ed. São Paulo( SP): Brasiliense, 1985.

CAVA, Ralph Della. Milagre em Joaseiro. Rio de Janeiro: Paz e Terra, 1976.

CERTEAU, Michel de. A invenção do cotidiano. 3. ed. Trad. Ephraim Ferreira Alves. Petrópolis(RJ): Vozes, 1998.

CHARTIER, Roger. À beira da falésia: a história entre incertezas e inquietudes. Trad. Patrícia Chittoni Ramos. Porto Alegre(RS): Ed. Universidade/UFRGS, 2002.

CHARTIER, Roger. A história cultural: entre práticas e representações. Trad. Maria Manuela Galhardo. Rio de Janeiro(RJ): Bertrand Brasil, 1990.

DIÁRIO DO COMÉRCIO. Curitiba: s/ed. , 30.01.1893. p.8.

ELIADE, Mircea. O sagrado e o profano. 1.ed. São Paulo(SP): Livraria Martins Fontes Editora Ltda, 1992.

FRANCO JÚNIOR, Hilário. Apresentação. In: VARAZZE, Jacopo de. Legenda Áurea: vidas de Santos. São Paulo: Companhia das Letras, 2003.

GAÊTA, Maria Aparecida Junqueira da Veiga. Corpo santo, alma santa: o culto e a devoção à Menina Izildinha em Monte Alto (1950-1997). 1999. Tese (Mestrado em História) Universidade Estadual Paulista "Júlio Filho de Mesquita" - Franca(SP), 1999.

GRASSI, Clarissa. Um olhar... a arte no silêncio. 1.ed. Curitiba(PR): Editora Clarissa Grassi, 2006.

HERVIEU- LÉGER, Danièle. O peregrino e o convertido: a religião em movimento. Vozes: Petrópolis(RJ), 2008.

JURKEVICS, Vera Irene. Os santos da igreja e os santos do povo: devoções e manifestações de religiosidade popular. Curitiba(PR): Universidade Federal do Paraná, 2004 .

KOSTER, Julia Impéria. A construção de uma santidade popular e os direitos da mulher. Âmbito Jurídico. Ano XIV, n. 86, Mar., 2011. Disponível em: 
<http://www.ambitojuridico.com.br/site/?n_link=revista_artigos_leitura\&artigo_id=9222\& revista_caderno=3> Consultado: 23 Abr. 2014.

LIMA, Andrea de Alvarenga. A saga de Maria Bueno: um retrato da alma de Curitiba. Psicologia Argumento. Ano III, v. 25, n. 49, p. 173-185, abr./jun., 2007. Disponível em: <http://www2.pucpr.br/reol/index.php/pa?dd1=1659\&dd99=view> Consulta: 14 Fev. 2014.

OTTO, Rudolf. O Sagrado. São Leopoldo: Sinodal/EST; Petrópolis: Vozes, 2007.

REIS, Martha dos. Iracema, a Santinha de Marília: um estudo sobre a criação de um imaginário popular. 1993. Tese (Mestrado em História) - Universidade Estadual Paulista, Assis(SP), 1993.

PEREIRA, Sebastião Izidoro. Maria Bueno. Curitiba - PR: Editora Gráfica Mundial, 1948.

PEREIRA, José Carlos. Sincretismo religioso e ritos sacrificiais. 1. ed. São Paulo: Zouk, 2004 .

PICCOLI, Tonia Kio Fuzihara. Pesquisa e observação participante Cemitério São Francisco de Paula, Curitiba-PR, 02/11/2013.

SANCHIS, Pierre. No mapa das religiões há lugar para a religiosidade? Revista de Ciências Humanas, n.30, jan. p.12-26, 2001. Disponível em:

<https://periodicos.ufsc.br/index.php/revistacfh/article/view/25109/22123>. Consulta: 25 Fev. 2015.

SAEZ, Oscar Calavia. Fantasmas falados: mitos e mortos no campo religioso brasileiro. Campinas(SP): Editora da UNICAMP, 1996.

SANTOS, Conceição Aparecida dos. Como nascem os santos: o caso Maria Bueno. 2010. Dissertação (Mestrado) - Universidade Federal do Paraná, Setor de Ciências Humanas, Letras e Artes, Programa de Pós - Graduação em Antropologia Social. Curitiba, 2010.

SMITH, Wilfred Cantwell. La religion comparada: ¿Donde y por que? In: Metologia de la historia de las religiones. Mircea Eiade; Joseph M. Kitagawa (Org). Trad. Saad Chedid e Eduardo Masullo. Buenos Aires: Paidós, 1967. p. 53-85.

STOLL, Sandra Jacqueline; SANTOS, Conceição dos; BRAGA, Geslline Giovana; DURANDO, Vanessa. Maria Bueno: Santa de Casa. 22 ed.. Curitiba: Edição do autor, 2011.

VAUCHEZ, André. Santidade. In: LE GOFF, Jacques (Dir.). Enciclopédia Einaudi. Lisboa: Imprensa Nacional Casa da Moeda, 1987. v.12, p.287-300.

ZALUAR, Alba. Os Homens de Deus. Um estudo dos santos e das festas no catolicismo popular. Rio de Janeiro(RJ): Zahar, 1983. 
Universidade do Estado de Santa Catarina - UDESC Programa de Pós-Graduação em História - PPGH

Revista Tempo e Argumento Volume 08 - Número 18 - Ano 2016 tempoeargumento@gmail.com 